\title{
Adverse physicochemical properties of tripalmitin in beta cells lead to morphological changes and lipotoxicity in vitro
}

Received: 8 February 2005 / Accepted: 21 April 2005 / Published online: 11 August 2005

(C) Springer-Verlag 2005

\begin{abstract}
Aims/hypothesis: Long-term exposure of beta cells to lipids, particularly saturated fatty acids in vitro, results in cellular dysfunction and apoptosis (lipotoxicity); this could contribute to obesity-related diabetes. Our aims were to relate cell death to intracellular triglyceride concentration, composition and localisation following incubation of INS1 cells in saturated and unsaturated NEFA in high and low glucose concentrations. Materials and methods: In sulin-producing INS1 cells were cultured (24 h; 3 and $20 \mathrm{mmol} / 1$ glucose) with palmitic, oleic or linoleic acids and the resulting intracellular lipids were analysed by gas chromatography and microscopy. Cell death was determined by quantitative microscopy and 3(4,5-dimethlthiazol-2-yl)-2,5-diphenyltetrazolium bromide (MTT) assay, and glucose-stimulated insulin secretion by ELISA. Results: All NEFA ( $0.5 \mathrm{mmol} / 1,0.5 \%$ albumin $)$ inhibited glucose-stimulated $(20 \mathrm{mmol} / \mathrm{l})$ insulin secretion. Cytotoxicity was evident only with palmitic acid $(p<0.05)$, in which case intracellular triglyceride consisted largely of tripalmitin in angular-shaped dilated endoplasmic reticulum. Cytotoxicity and morphological disruption were reduced by addition of unsaturated NEFA. Triglyceridecontent (control cells; $14.5 \mathrm{ng} / \mu \mathrm{g}$ protein) increased up to 10 -fold following incubation in NEFA (oleic acid $153.2 \mathrm{ng} / \mu \mathrm{g}$ protein; $p<0.05$ ) and triglyceride and phospholipid fractions were both enriched with the specific fatty acid added to the medium $(p<0.05)$. Conclusions/ interpretation: In INS1 cells, palmitic acid is converted
\end{abstract}

J. H. Moffitt · B. A. Fielding · J. M. Currie $\cdot$ A. Clark $(\bowtie)$

Oxford Centre for Diabetes,

Endocrinology and Metabolism,

Churchill Hospital,

Oxford, OX3 7LJ, UK

e-mail: anne.clark@drl.ox.ac.uk

Tel.: +44-1865-857225

Fax: +44-1865-857217

R. Evershed · R. Berstan

Organic Geochemistry Unit,

Biogeochemistry Research Centre,

School of Chemistry,

University of Bristol,

Bristol, BS8 1TS, UK in the endoplasmic reticulum to solid tripalmitin (melting point $>65 \mathrm{C}$ ), which could induce endoplasmic reticulum stress proteins and signal apoptosis; lipid-induced apoptosis would therefore be a consequence of the physicochemical properties of these triglycerides. Since cellular triglycerides composed of single species of fatty acid are not likely to occur in vivo, destruction of beta cells by saturated fatty acids could be predominantly an in vitro scenario.

Keywords Beta cell · ER stress · INS1 - Insulin · Lipotoxicity $\cdot$ Oleate $\cdot$ Palmitate $\cdot$ Phospholipid . Triglyceride $\cdot$ Tripalmitin

Abbreviations GSIS: glucose-stimulated insulin secretion - ER: endoplasmic reticulum - TG: triglyceride DGAT: diacylglycerol acyl transferase - PFA:

paraformaldehyde · KRH: Krebs-Ringer HEPES - HTGC: high-temperature gas chromatography

\section{Introduction}

Sustained elevated lipid concentrations result in impaired insulin action and secretion in vivo and in vitro; this has implications for obesity-related diabetes [1-3]. It is known that increased plasma NEFA concentrations reduce insulinmediated glucose uptake and metabolism in muscles - the Randle effect [4] — but the exact mechanism of action of NEFA on the beta cell to modulate glucose-stimulated insulin secretion (GSIS) $[5,6]$ is not known. A complex inter-relationship between the metabolism of glucose and lipids in beta cells has been described [7], and this is modified by the duration of exposure (acute or chronic) to the lipid metabolites $[5,6,8]$.

A variety of mechanisms have been proposed to explain NEFA-induced inhibition of GSIS. In response to prolonged exposure of beta cells to NEFA and hyperglycaemia, fatty acids are deviated from beta-oxidation to alternative pathways, such as storage as triglycerides (TGs), possibly mediated by increased malonyl CoA [9]. These 
intracellular TGs could provide an energy store, being later hydrolysed by lipases such as hormone-sensitive lipase [10], and undergo beta-oxidation [11]. Hence, TG accumulation could play a role in inhibition of GSIS. The intermediates of lipid metabolism change expression of beta cell genes and proinsulin biosynthesis $[12,13]$, and NEFA or their metabolites have been proposed to increase uncoupling protein 2 and modulate insulin secretion through decreased production of ATP $[14,15]$. NEFA have also been shown to reduce cellular viability and induce beta-cell apoptosis [16]. NEFA, and particularly saturated NEFA such as palmitic acid [17-19], have been identified as toxic agents which activate signalling cascades that result in apoptotic beta-cell death [20,21].

However, the hypothesis of NEFA-induced beta-cell death cannot play a major role in the pathophysiology of human diabetes. Although increased plasma NEFA concentrations and composition occur in obesity in humans [22], this condition is not invariably linked to the onset of type 2 diabetes; fewer than $12 \%$ of obese subjects with elevated lipid profiles have diabetes [23, 24]. Furthermore, the concept of 'glucolipotoxity' $[25,26]$ proposes that, in diabetes, the elevation of glucose and NEFA could contribute to the decrease in pancreatic islet function as a result of both beta-cell apoptotic death and decreased insulin secretion of type 2 diabetes. Our aims were to compare the effects of saturated and unsaturated NEFA in high and low glucose concentrations in INS1 cells. These effects were evaluated by measurement of GSIS, cell death and TG concentration, composition and localisation.

\section{Materials and methods}

\section{Cell culture conditions}

INS1 beta cells (rat insulinoma, passage 9-19) were cultured in RPMI 1640 (Sigma, Poole, UK), $11 \mathrm{mmol} / 1$ glucose, $10 \%$ fetal bovine serum (FBS), $2 \mathrm{mmol} / \mathrm{l} \mathrm{L}$-glutamine, $50 \mu \mathrm{mol} / 1 \beta$-mercaptoethanol, $10 \mathrm{mmol} / \mathrm{l} \mathrm{HEPES}$, $1 \mathrm{mmol} / \mathrm{l}$ sodium pyruvate, $50 \mathrm{U} / \mathrm{ml}$ penicillin and $50 \mu \mathrm{g} /$ $\mathrm{ml}$ streptomycin (Gibco, Paisley, UK) in $5 \% \mathrm{CO}_{2}$. COS7 cells (monkey kidney fibroblasts) were cultured in RPMI $1640,11 \mathrm{mmol} / 1$ glucose, $10 \% \mathrm{FBS}, 2 \mathrm{mmol} / 1 \mathrm{~L}$-glutamine, $50 \mathrm{U} / \mathrm{ml}$ penicillin and $50 \mu \mathrm{g} / \mathrm{ml}$ streptomycin (Gibco) in $5 \% \mathrm{CO}_{2}$.

\section{Preparation of fatty acids}

Potassium salts of palmitic, oleic and linoleic acids (Sigma) were bound to $10 \%$ fatty acid-free BSA in RPMI to make $10 \mathrm{mmol} / 1$ stock solutions and were diluted for use to give a final concentration of fatty acid $0.5 \mathrm{mmol} / \mathrm{l}$, BSA $0.5 \%$ unless otherwise stated. These fatty acid concentrations were confirmed by enzymatic (Wako, Neuss, Germany) analysis on the IL Monarch automated analyser (Instrumentation Laboratory, Warrington, UK) and composition was confirmed using gas chromatography (described below).
Cell viability: MTT assay

INS1 cells were plated into 96 -well plates at $5 \times 10^{4}$ cells per well. Cells were treated with NEFA as described for light microscopic and insulin secretion experiments. After $24 \mathrm{~h}$, $10 \mu \mathrm{l}$ of 3-(4,5-dimethylthiazol-2-yl)-2,5-diphenyltetrazolium bromide (MTT) at $5.5 \mathrm{mg} / \mathrm{ml}$ in PBS was added and the cells were incubated for $2 \mathrm{~h}$. The medium was removed and the cells were lysed with $100 \mu \mathrm{l}$ propan-2-ol. The absorbance was measured at $550 \mathrm{~nm}$ (Bichromatik; Labsystems, Altringham, UK).

Cell viability: quantitative light microscopy

INS1 cells were plated into eight-well Permanox slides (Gibco) and treated for $24 \mathrm{~h}$ with $0.1,0.25,0.5$ and $1 \mathrm{mmol} / 1$ of NEFA in 3 or $20 \mathrm{mmol} / \mathrm{l}$ glucose. Adjustments to the stock solution were made to ensure a constant albumin concentration. Following incubation, cells were rinsed in PBS, incubated for a further $30 \mathrm{~min}$ in PBS containing $10 \mu \mathrm{mol} / 1$ calcein $\mathrm{AM}$ (Sigma) at $37^{\circ} \mathrm{C}$ and fixed in $2.5 \%$ paraformaldehyde (PFA) for $30 \mathrm{~min}$. Slides were rinsed twice more in PBS and the slides mounted in Vectorshield containing propidium iodide (Vector Laboratories, Burlingame, CA, USA). Viability was quantified by counting the propidium-iodide-positive nuclei and calcein-AM-positive cells (average cell count $=60$ cells per field) and determining the percentage of propidium-iodide-positive nuclei in at least three fields of view per condition.

\section{Insulin secretion}

INS1 cells $\left(5 \times 10^{4}\right.$ per well in 12 -well plates $)$ were treated with RPMI containing 3 or $20 \mathrm{mmol} / 1$ glucose and $0.5 \mathrm{mmol} / 1 \mathrm{NEFA}$ or a mixture of oleic and palmitic acids in equal ratio, with a total concentration of $0.5 \mathrm{mmol} / \mathrm{l}$. Control wells contained $0.5 \%$ fatty acid-free BSA in medium. After $24 \mathrm{~h}$, the cells were washed in PBS and preincubated for $2 \mathrm{~h}$ in Krebs-Ringer HEPES (KRH) buffer containing $3 \mathrm{mmol} / \mathrm{l}$ glucose $(119 \mathrm{mmol} / 1 \mathrm{NaCl}, 4.75 \mathrm{mmol} / \mathrm{l}$ $\mathrm{KCl}, 5 \mathrm{mmol} / 1 \mathrm{NaHCO}_{3}, 1.2 \mathrm{mmol} / 1 \mathrm{MgSO}_{4}, 1.18 \mathrm{mmol} / \mathrm{l}$ $\mathrm{KH}_{2} \mathrm{PO}_{4}, 20 \mathrm{mmol} / \mathrm{l} \mathrm{HEPES}$, pH 7.4, $2.54 \mathrm{mmol} / \mathrm{CaCl}_{2}$ ). Glucose responsiveness was evaluated by an initial 30-min incubation in $\mathrm{KRH}$ containing $3 \mathrm{mmol} / \mathrm{l}$ glucose followed by incubation for $30 \mathrm{~min}$ in $\mathrm{KRH}$ containing $20 \mathrm{mmol} / 1$ glucose. Samples were collected for insulin measurement using ELISA (Diagenics, Milton Keynes, UK); CV 4.5\% and minimal detection $0.15 \mu \mathrm{g} / \mathrm{l}$.

Triacylglycerol and phospholipid content and composition

INS1 or COS7 cells were seeded into six-well plates at $2 \times 10^{5}$ cells per well and treated for $24 \mathrm{~h}$ with $0.5 \mathrm{mmol} / \mathrm{l}$ specific fatty acids as above. Total lipids were extracted from cells in 2:1 chloroform:methanol and lipid fractions 
were separated using solid-phase extraction [27]. The triacylglycerol and phospholipid fractions were collected and fatty acid methyl esters prepared using methanolic sulphuric acid. The fatty acid methyl esters were separated by gas chromatography using an Agilent 6890 GC equipped with a DB-Wax $30 \mathrm{~m}$ capillary column coated with a polyethylene glycol stationary phase (internal diameter $0.25 \mathrm{~mm}$, film thickness $0.25 \mu \mathrm{m}$; Agilent Technologies, South Queensferry, UK). Fatty acids were separated according to fatty acyl carbon chain length and degree of saturation. Intact TG analyses were performed by hightemperature gas chromatography (HTGC) on a Hewlett Packard 5890 series II GC with a DB1-HT $15 \mathrm{~m}$ fused silica capillary column (internal diameter $0.32 \mathrm{~mm}$, film thickness $0.1 \mathrm{~mm}$; J \& W Scientific, Stockport, UK). Hydrogen was the carrier gas and a flame ionisation detector was employed to monitor column eluent. HTGC analyses separated the TGs according to their carbon number. Baseline resolution, however, could not be achieved to determine the degree of unsaturation. The absolute concentrations of individual fatty acids and TGs were determined by reference to internal standards (heptadecanoic acid [17:0] for NEFA; tripentadecanoin [15:0] for triacylglycerol; phosphatidylcholine, diheptadecanoyl [17:0] for phospholipid).

\section{Light microscopy}

INS1 and COS7 cells were incubated in eight-well Permanox or glass slides (Gibco) for $24 \mathrm{~h}$ in 3 or $20 \mathrm{mmol} / 1$ glucose with and without NEFA. Cells were washed in PBS and fixed in $2.5 \%$ PFA then stained for lipids. A stock solution of $0.5 \%$ (saturated) oil red $\mathrm{O}$ in propan-2-ol was freshly diluted (three parts stock solution in two parts distilled water) and filtered immediately before use. Cells were stained for $30 \mathrm{~min}$ at $37^{\circ} \mathrm{C}$ then briefly destained in $60 \%$ isopropanol and washed in water before mounting in PBS/glycerol.

A freshly prepared $1 \%$ Nile blue solution in distilled water was filtered and an aliquot was further diluted in water to $0.02 \%$. Fixed cells were washed twice in PBS. Nile blue solution (1\%) was added to the cells for $10 \mathrm{~min}$ at 65 or $70^{\circ} \mathrm{C}$, after which the cells were washed in water and destained in $1 \%$ acetic acid $\left(65^{\circ} \mathrm{C}\right)$ for $30 \mathrm{~s}$. Cells were restained for $15 \mathrm{~min}$ in $0.02 \%$ Nile blue at 65 or $70^{\circ} \mathrm{C}$ before being washed in water and mounted in PBS/ glycerol.

\section{Electron microscopy}

INS1 and COS7 cells for morphological analysis were incubated in $25 \mathrm{~cm}^{2}$ flasks for $24 \mathrm{~h}$ as described above. Cells were removed and gently prepared as a pellet, fixed in $2.5 \%$ glutaraldehyde (minimum $1 \mathrm{~h}$ ) at room temperature (or for a 10 -min period at $70^{\circ} \mathrm{C}$ ), postfixed in $2 \%$ osmium, dehydrated and embedded in Spurr's resin. Cells for immunoelectron microscopy were fixed in ice-cold $4 \%$ PFA (10 min) followed by $8 \%$ PFA at room temperature
(50 min), washed in PBS, dehydrated in methanol and embedded in LR Gold resin. Ultrathin sections were cut onto nickel grids and contrast-enhanced with uranyl acetate and lead citrate. Immunolabelling for protein disulphide isomerase used methods described previously [28] and $15 \mathrm{~nm}$ protein A gold (Biocell, Cardiff, UK). Sections were examined in the Joel 1010 microscope with an accelerating voltage of $80 \mathrm{kV}$.

\section{Statistical analysis}

All results are expressed as means $\pm \mathrm{SEM}$ of three or more experiments. Statistical significance was calculated using ANOVA followed by post-hoc analysis; a $p$ value $<0.05$ was considered significant.

\section{Results}

Reduced cellular viability is more pronounced with palmitic acid than with oleic or linoleic acids

The proportion of non-viable cells was not significantly increased following incubations with NEFA at 0.1 and $0.25 \mathrm{mmol} / 1$ (Fig. 1a). At $0.5 \mathrm{mmol} / 1$ there was an increase in non-viable cells following culture with palmitic acid, which was significant at high glucose concentration $(p<$ 0.05 ), but there was no effect with the unsaturated NEFA. At $1 \mathrm{mmol} / 1$, the number of non-viable cells was increased with all three NEFA; it is likely that the albumin available to bind fatty acids at this concentration was insufficient. Palmitic-acid-induced cytotoxicity can be rescued by addition of unsaturated NEFA [29, 30]. Mixtures of palmitic and oleic acid showed increased cell viability compared with palmitic acid alone (Fig. 1b). Cells labelled with propidium iodide (nuclear marker for cell death) and calcein AM (cytoplasmic label for viable cells) (Fig. 1c) demonstrated similar results; cell death increased with increasing NEFA concentrations and palmitic acid induced the highest degree of cytotoxicity. These data established that culture of cells in NEFA $(0.5 \mathrm{mmol} / \mathrm{l})$ was appropriate for estimation of TG content and morphological studies without excessive cell death.

NEFA inhibits glucose stimulated insulin secretion

Following 24 h of incubation with NEFA, INS1 cells had elevated basal insulin secretion but failed to respond to glucose (Fig. 2). Glucose $(20 \mathrm{mmol} / \mathrm{l})$ failed to elicit a significant increase in insulin secretion following incubation with palmitic, oleic or linoleic acids or with a mixture of 1:1 palmitic and oleic acids (Fig. 2). INS1 cells cultured in $20 \mathrm{mmol} / 1$ glucose with or without NEFA for $24 \mathrm{~h}$ did not respond to a glucose stimulus. This confirms the susceptibility of beta cells to chronic exposure to glucose [31]. 


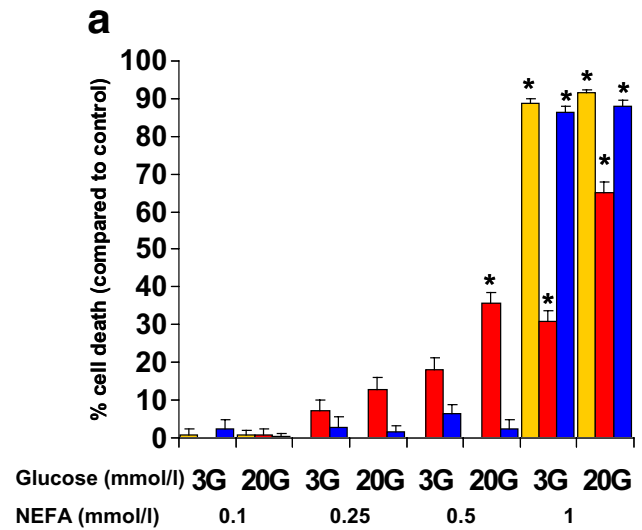

Fig. 1 a The proportion of non-viable INS1 cells (MTT assay) was not significantly increased following incubation with NEFA at 0.1 or $0.25 \mathrm{mmol} / 1$ compared with cells incubated without NEFA. At $0.5 \mathrm{mmol} / 1 \mathrm{NEFA}$, cell death was induced by palmitic acid (red) but not by oleic (yellow) or linoleic acid (blue). b Mixtures of oleic and

Triglyceride content and composition

INS1 cells incubated with NEFA and $20 \mathrm{mmol} / 1$ glucose had a higher concentration of total cellular TGs compared with cells cultured in the absence of NEFA (Fig. 3a). The degree of accumulation increased up to six-fold in cells incubated in NEFA in combination with $20 \mathrm{mmol} / 1$ glucose compared with that observed at $3 \mathrm{mmol} / \mathrm{l}$ glucose. TG content at $20 \mathrm{mmol} / \mathrm{l}$ glucose was highest with oleic acid

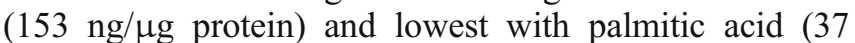
$\mathrm{ng} / \mu \mathrm{g}$ protein). In addition, the composition of total TG was significantly enriched with the fatty acids in which the cells were incubated.

The TG content of cells exposed to palmitic acid was increased when oleic acid was substituted in the culture medium to make mixtures of oleic and palmitic acids. This increased TG had a higher palmitate content despite the lower concentration of palmitic acid $(<0.05 \mathrm{mmol} / \mathrm{l})$ in the culture medium (Fig. 3b) compared with palmitic acid alone, suggesting that greater uptake and storage of sat-

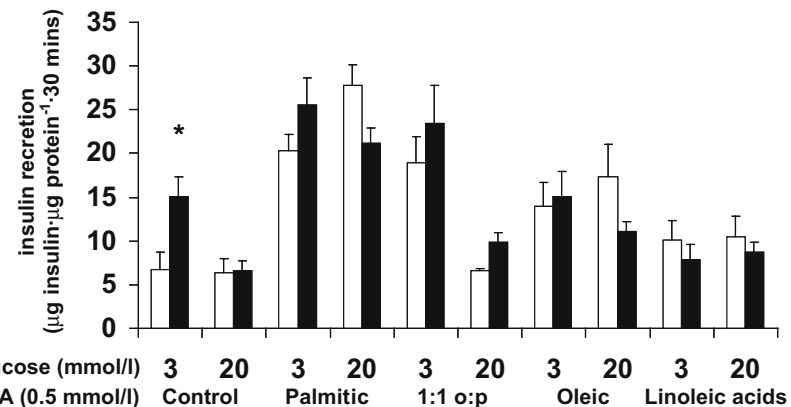

Fig. 2 Insulin secretion into the media following 24-h incubation with palmitic, oleic and linoleic acids $(0.5 \mathrm{mmol} / \mathrm{l})$ and 3 or $20 \mathrm{mmol} /$ 1 glucose. Secretion was increased at basal glucose $(3 \mathrm{mmol} / \mathrm{l}$; white bars) and cells failed to respond to elevated glucose $(20 \mathrm{mmol} / \mathrm{l}$; black bars). A 1:1 mixture of oleic (o) and palmitic acids (p) caused similar loss of glucose sensitivity. Means \pm SEM; at least three separate experiments $\left({ }^{*} p<0.05\right)$ b

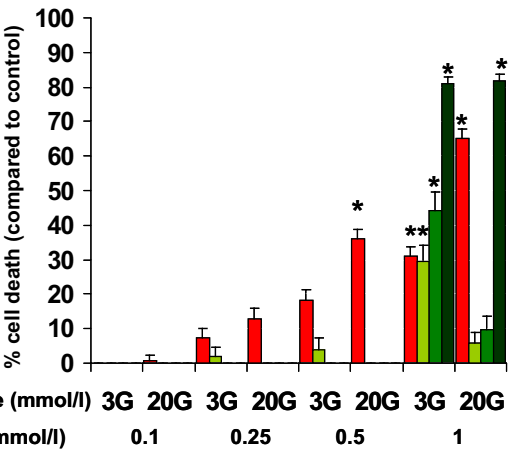

palmitic acid (1:2 oleic [o]: palmitic acid [p] [light green]; 1:1 o:p mixture [green] and 2:1 o:p mixtures [dark green]) were less toxic at $0.5 \mathrm{mmol} / 1$ than palmitic acid alone $(\mathrm{red})$. At $1 \mathrm{mmol} / 1 \mathrm{NEFA}$ there was an increase in the number of non-viable cells in all conditions. Means \pm SEM, three separate experiments $\left({ }^{*} p<0.05\right)$

urated lipid is facilitated by the presence of unsaturated lipid.

Following incubation in high glucose and palmitic acid, $75 \%$ of the TG stored in INS1 cells was found by HTGC to contain 48 acyl carbon atoms, e.g. $3 \times 16$-carbon fatty acids (Fig. 3c). These TGs are likely to be mostly tripalmitin since gas-chromatographic analysis of fatty acid methyl esters, prepared after hydrolysis, revealed negligible amounts of palmitoleic (16:1 n-7) and myristic acids (14:0). In mixtures of 1:1 oleic:palmitic acid, the relative proportions of TG species were consistent with random esterification of available fatty acids; the percentages of tripalmitin (PPP, Fig. 3c) and triolein (OOO, Fig. 3c) stored in the cells were both exactly $13.8 \%$. The proportion of dipalmitoyl oleoyl glycerol (PPO/POP) and dioleoyl palmitoyl glycerol (OOP/ OPO) were 35 and $33 \%$, respectively.

The TG content of COS7 cells was higher than that of INS1 cells (Fig. 3d). Following incubation with $0.5 \mathrm{mmol} / 1$ oleic or palmitic acid, intracellular TG content increased 15-fold (from 3.1 to $49.1 \mu \mathrm{g}$ ) and 10-fold (from 3.1 to $31.4 \mu \mathrm{g}$ ) respectively. In COS7 cells incubated in oleic acid, formation of triolein accounted for $73 \%$ of total TGs; when incubated in palmitic acid, tripalmitin accounted for $76 \%$ of total TGs.

Phospholipid fatty acid composition

Fatty acid composition of the phospholipid fraction of INS1 cells was significantly altered by incubation in different NEFA species (Fig. 4) $(p<0.05)$. Following incubation in palmitate a two-fold increase in the proportion of palmitic acid in phospholipids was observed. Similarly, in cells treated with oleic acid, the proportion increased 2.4fold and a dramatic increase was seen with linoleate, which increased from $5 \%$ to almost $50 \%$ of the total phospholipid fatty acids. In contrast to cellular TG fractions, incorporation of fatty acids into phospholipids was not significantly affected by glucose. 
a

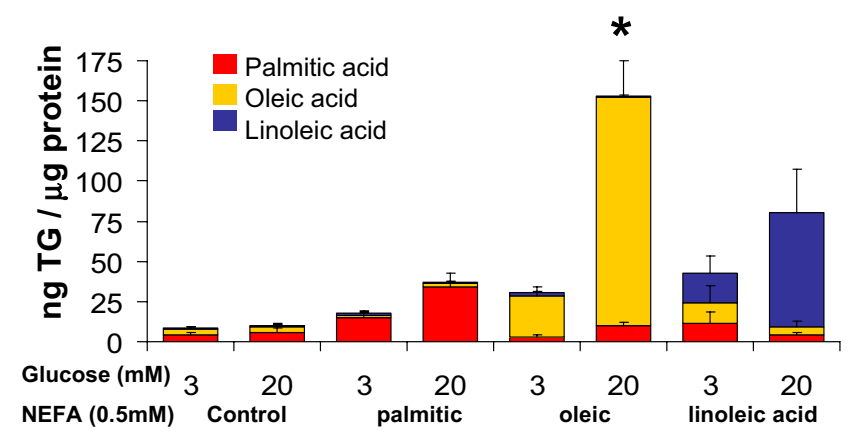

C

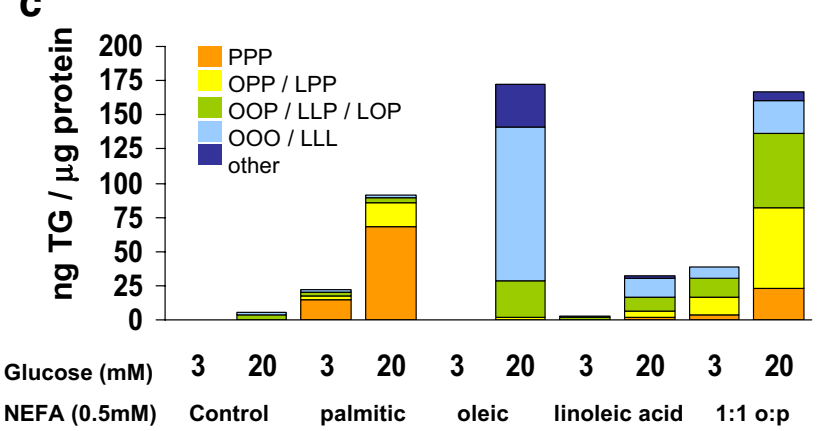

Fig. 3 Total TG content, fatty acid composition (a, b, d) and molecular species of intracellular TG (c, d) in INS1 and COS7 cells. Colour key, TG (a, b, d): palmitic acid, red; oleic acid, yellow; linoleic acid, blue. Colour key, molecular species: (c) orange, PPP; pale yellow, OPP/LPP; green, OOP/LLP/LOP; blue, OOO/LLL; dark blue, other; (d): orange, PPP; pale yellow, OPP/POP; green, $\mathrm{OOP} /$ OPO; blue, OOO; dark blue, other. (a) Total TG content was increased in INS1 cells following incubation with NEFA in combination with high glucose. Fatty acid composition of the TG was specifically enriched with the incubating NEFA. Total TG content was highest with oleic acid and lowest with palmitic acid. (b) Mixtures of oleic $(o)$ and palmitic acids $(p)$ in varying ratios induced greater total TG content than palmitic acid alone. The fatty acid b
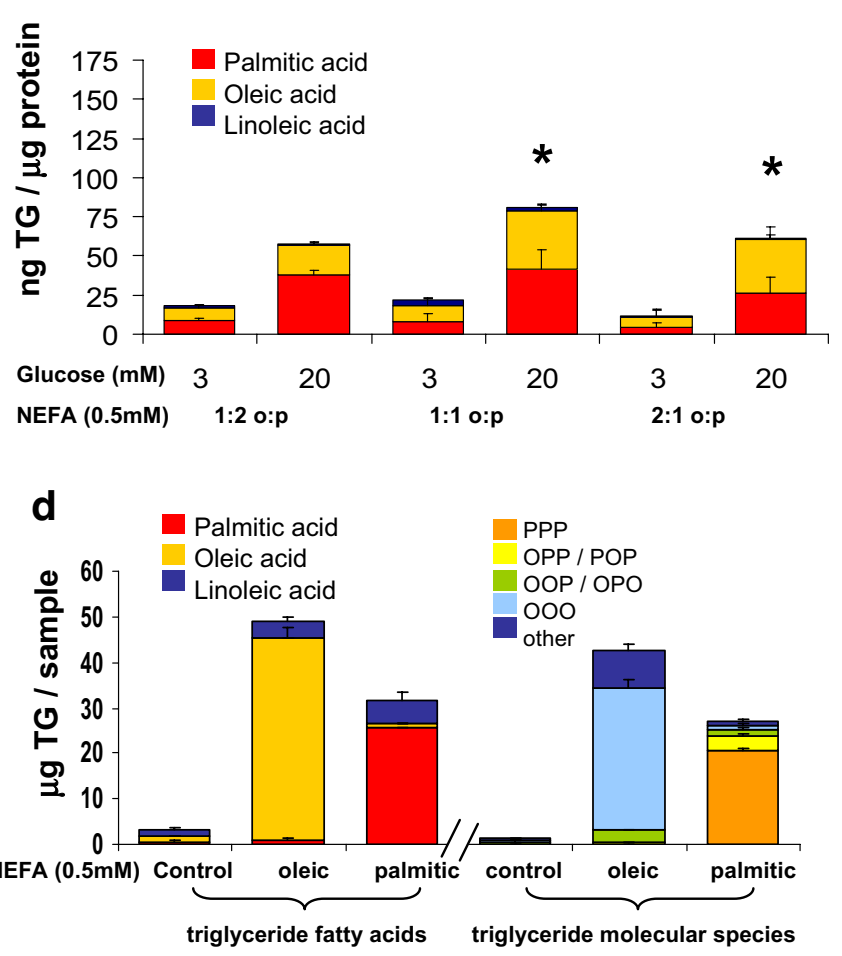

composition of TG reflected the relative proportions of oleic and palmitic acid in the media. (c) The molecular species of accumulated TG was determined. Tripalmitin (PPP) was the predominant TG in cells incubated in palmitic acid. Triolein (OOO) was the predominant TG in cells incubated in oleic acid $(20 \mathrm{mmol} / 1$ glucose $)$. In mixtures of 1:1 oleic to palmitic acid the relative proportions of TG species were consistent with random esterification of available fatty acids. (d) In COS7 cells total TG content was increased following incubation with NEFA. TG fatty acid reflected the incubating NEFA, and following incubation in oleic or palmitic acid, molecular species were mainly triolein (OOO) or tripalmitin (PPP) respectively. Means $\pm \mathrm{SEM} ;{ }^{*} p<0.05$ compared with control

\section{Morphology of intracellular TG}

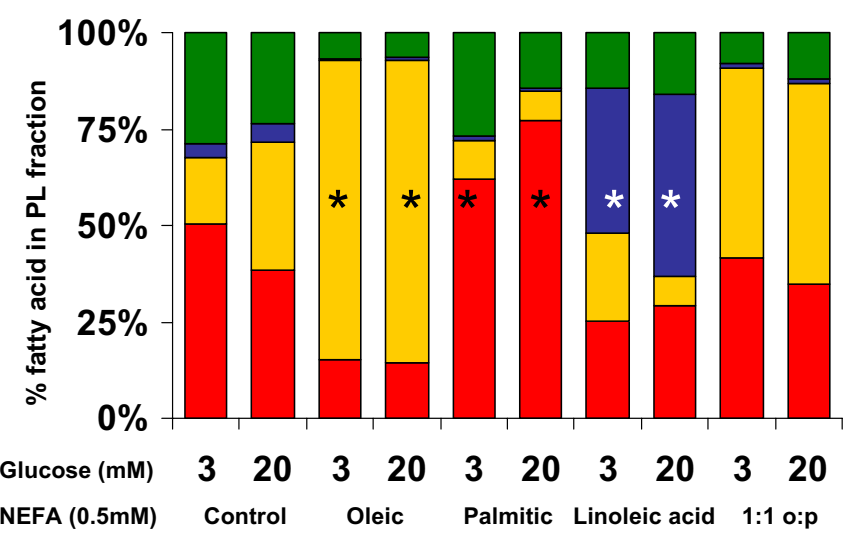

Fig. 4 Phospholipid fatty acid composition was altered following incubation in $0.5 \mathrm{mmol} / 1$ palmitic acid, oleic acid or linoleic acid or in a 1:1 mixture of oleic and palmitic acids. The enrichment with palmitic, oleic and linoleic acid was statistically significant $\left({ }^{*} p<0.05\right)$. The percentage of total phospholipid containing palmitic (red), oleic (yellow), linoleic (blue) or other fatty acids (green) are shown for each condition
Light and electron microscopic observations demonstrated cells exposed to NEFA. COS7 cells were included to demonstrate that the effects of NEFA were not restricted to beta cells. Lipid droplets in the cytoplasm were visible following exposure to NEFA (Fig. 5a-c and e-f). This was particularly apparent in cells cultured with either linoleic or oleic acid. Cells exposed to palmitic acid showed a different pattern of lipid distribution (Fig. 5d,g); in these cells, oil red O-labelled material was more diffuse and associated with large vacuolated regions of the cytoplasm (Fig. $5 \mathrm{~d}, \mathrm{~g}$ ). The degree of lipid accumulation was increased by glucose, consistent with the quantitative observations of TG content in cell extracts.

To demonstrate that the accumulated lipids were neutral lipids (TG), INS1 and COS7 cells were labelled with Nile blue sulphate (Fig. 6). The oxazones in Nile blue sulphate are soluble in neutral lipid and stain red in visible light [32]. lipid accumulations in the cytoplasm of INS1 and COS7 
Fig. 5 Oil red O (ORO) staining of INS1 and COS7 cells exposed to NEFA $(0.5 \mathrm{mmol} / \mathrm{l}$; $24 \mathrm{~h}$ ) to localise intracellular lipid. a No ORO staining in control INS1 cells. b INS1 cells treated with oleic acid, $3 \mathrm{mmol} / \mathrm{l}$ glucose had few small red droplets. c Numerous large red droplets were seen in the cytoplasm of INS1 cells incubated with oleic acid, $20 \mathrm{mmol} / \mathrm{l}$ glucose. d No droplets were observed in palmitic acid-treated INS1 cells but diffuse red cytoplasmic staining was seen in some cells. e COS7 cells incubated in the absence of NEFA (11 mmol/1 glucose) contained a few small ORO positive droplets. f Many large OROpositive droplets were present following incubation in oleic acid. g No droplets but diffuse red cytoplasmic staining was seen in palmitic-acid-treated COS7 cells. Scale bars $=10 \mu \mathrm{m}$
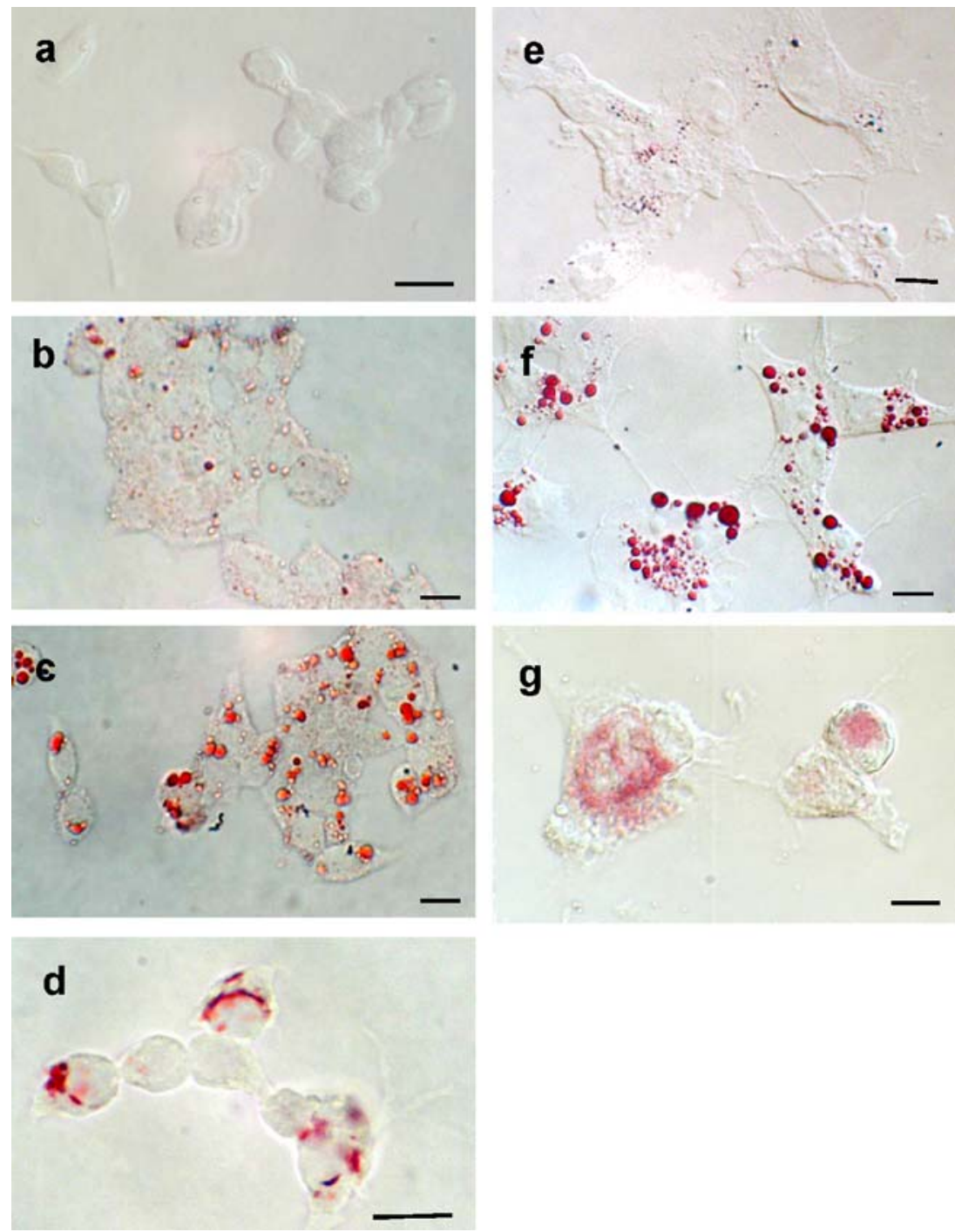

A few small lipid droplets were present in control cells (Fig. 6a,e). The size and number of droplets increased following exposure to oleic acid but cells exposed to palmitic acid showed few droplets, and large cytoplasmic vacuoles were prominent. Some of these vacuoles were labelled for neutral lipid (Fig. 6g). Since the melting temperature of tripalmitin is $66^{\circ} \mathrm{C}$, it was possible that the dyes were not penetrating the solid in cells exposed to palmitic acid. Nile blue staining was therefore performed at $70^{\circ} \mathrm{C}$ and neutral lipid became visible within the vacuoles (Fig. 6h)

Large lipid droplets were observed in the cytoplasm of INS1 and COS7 cells exposed to linoleic and oleic acids by electron microscopy (Fig. 7b, d, f) but angular vacuoles were the dominant feature of cells exposed to palmitic acid; no droplets were observed in INS1 cells either under control conditions or with palmitic acid treatment (Fig. 7a,c). Some small droplets were present in COS7 cells under these conditions (Fig. 7e). Droplets were formed in cells exposed to 2:1 oleic:palmitic acid mixtures (Fig. 7i) but rarely in cells exposed to 1:2 oleic:palmitic acid mixtures (Fig. $7 \mathrm{j}$ ). There was a corresponding decrease in the occurrence of cells containing vacuoles from $94 \%$ in $1: 2$ oleic:palmitic acid to $27 \%$ in $2: 1$ oleic:palmitic acid mixtures. The vacuoles were confirmed to be expanded endoplasmic reticulum (ER) by labelling with an antibody to protein disulphide isomerase, an enzyme resident in the rough ER (Fig. 7k); gold labelling was present in the ER of all cells and adjacent to the membranes of the lipidfilled vacuoles in palmitic acid-treated cells (Fig. 7k). The terminal enzymes for TG synthesis, diacylglycerol acyl transferase (DGAT) 1 and 2, are thought to be located in smooth ER in hepatocytes and enterocytes [33]; however, this is the first demonstration of TG accumulation in the ER of beta cells, suggesting a similar location of TG synthesis. Lipid droplets resulting from oleic or linoleic acid uptake were not found in the ER but were located without a boundary membrane in the cytoplasm. Cells exposed to palmitic acid frequently showed damaged mitochondria and DNA redistribution consistent with apoptosis; these features were not evident in cells exposed to linoleic or oleic acid. To determine if the vacuoles contained a material which was temperature-sensitive, palmitic acidcultured preparations were heated to $70^{\circ} \mathrm{C}$ for a short 
Fig. 6 Nile blue staining of INS1 and COS7 cells exposed to NEFA $(0.5 \mathrm{mmol} / \mathrm{l} ; 24 \mathrm{~h})$ with differentiated neutral lipid appearing red. a INS1 control; blue staining of cytoplasmic lipids. b INS1 in oleic acid; large red-coloured droplets are distributed throughout the cytoplasm. c INS1 in palmitic acid; absence of red colour but vacuoles are visible as splits in the cytoplasm (arrows). d Numerous red droplets were present in INS1 cultured with linoleic acid. e The COS7 control had no red lipid droplets. f COS7 cultured in oleic acid had numerous red cytoplasmic droplets. g COS7 cultured in palmitic acid demonstrated vacuoles in the cytoplasm (arrows) but little red labelling. h Palmitic acid-treated COS7 cells stained at $70^{\circ} \mathrm{C}$ to reveal small red droplets in the cytoplasm. Scale bars $=10 \mu \mathrm{m}$
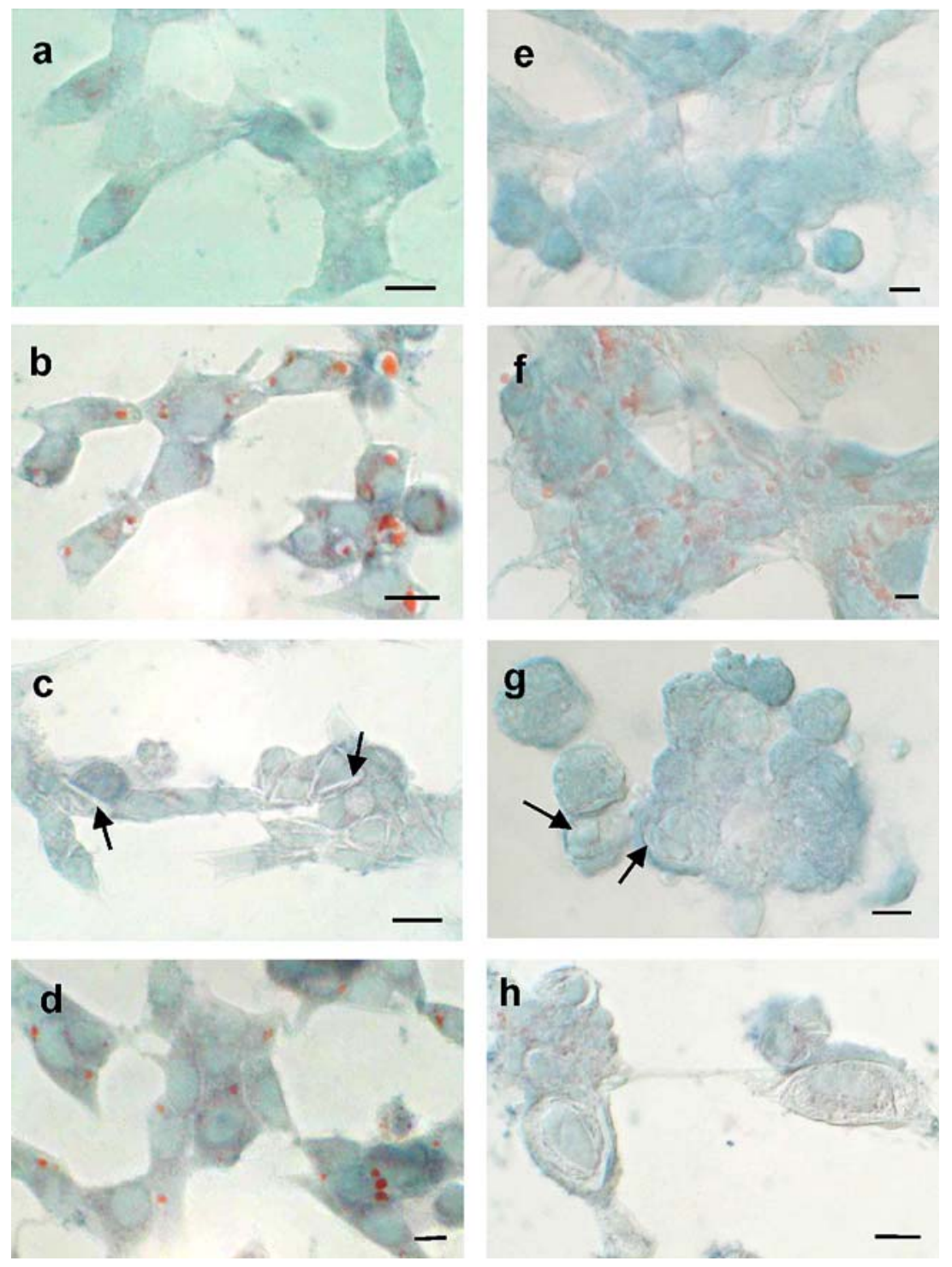

period (10 min) during fixation. This resulted in COS7 and INS1 cells having droplets within the expanded ER that were not visible with fixation at room temperature (Fig. 7h).

\section{Discussion}

Currently there is major interest in cell death following chronic exposure to lipids; this concept of NEFA-induced beta-cell death has been extended to the pathophysiology of type 2 diabetes, in which circulating NEFA levels are high $[34,35]$. In vitro studies on islets and clonal beta cells have shown that saturated fatty acids, such as palmitic and stearic acids, are particularly cytotoxic compared with unsaturated oleic or linoleic acid [17], although unsaturated NEFA are not entirely without cytotoxic properties [36]. Nevertheless, palmitic acid is the NEFA of choice for many islet and cell experiments. In agreement with these findings, cytotoxicity was greatest in the presence of palmitic acid and elevated glucose and lowest with oleic acid in INS1 cells. However, we found that inhibition of glucosestimulated insulin secretion by chronic exposure to NEFA occurs with both saturated and unsaturated lipids, as previously described [37]. We used new approaches to determine the relationship between inhibition of GSIS and the composition and localisation of intracellular TGs, demonstrating that, under in vitro conditions, palmitic-acidinduced lipotoxicity results from the formation of insoluble tripalmitin which accumulates in the ER of beta cells.

Our data show that incubation of INS1 cells with single specific fatty acids resulted in the accumulation of cellular TG with a distinct composition that reflected the fatty acid species. This suggested that there was no mixing of the exogenous fatty acids with the endogenous pool.

Moreover, our data indicate that cell death, which was highest with palmitic acid, was related to the formation of TG molecules incorporating palmitic acid and, in particular, tripalmitoyl glycerol (tripalmitin); these TGs are relatively solid at $37^{\circ} \mathrm{C}$, which would have implications for 

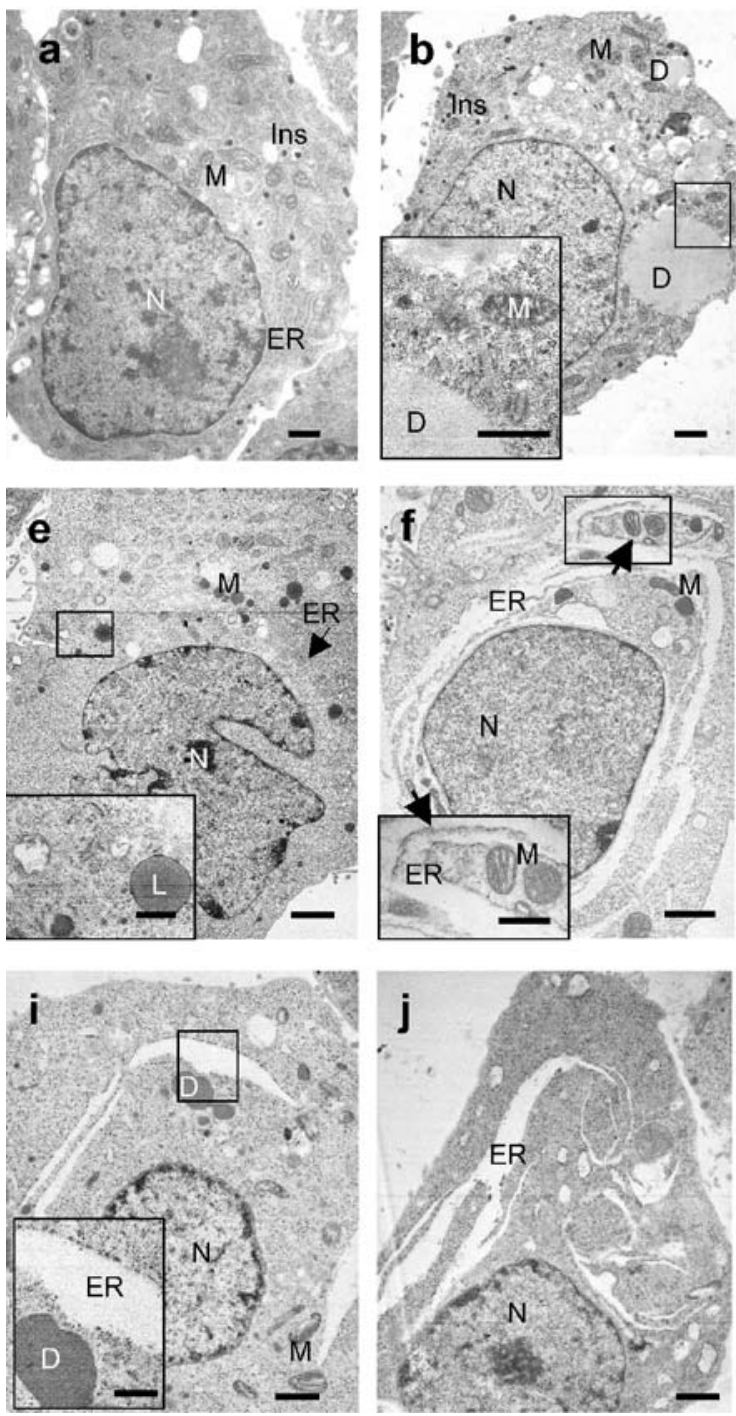

Fig. 7 Electron micrographs of lipid storage sites in INS1 and COS7 cells exposed to $0.5 \mathrm{mmol} / 1 \mathrm{NEFA}$. (a) INS1 control contained secretory granules. (b) INS1 incubated with oleic acid contained electron opaque droplets in the cytoplasm (inset). Mitochondria appeared normal. (c) INS1 exposed to palmitic acid had characteristic angular vacuoles throughout the cell. These were lined with ribosomes (arrows in inset) in some regions, suggesting distended endoplasmic reticulum (d) INS1 cultured with linoleic acid contained electron-dense droplets (inset). (e) COS7 control condition. These larger cells have lysosomes containing lipid-like material (inset). (f) COS7 incubated with palmitic acid, showing angular vacuoles lined with ribosomes (arrows), as seen in the INS1 cells. No droplets were apparent and mitochondria were normal. (g) COS7 incubated with palmitic acid and heated to $70^{\circ} \mathrm{C}$ for 10 min during fixation. Electron-dense droplets appeared in these cells, adjacent to or with-

the cellular handling of TGs. Oil red $\mathrm{O}$ and Nile blue staining demonstrated a unique distribution of neutral lipid in cells loaded with palmitate; lipid was present in vacuoles throughout the cytoplasm rather than in droplets (Fig. 5d,g); and these were identified by immunoelectron microscopy to be dilated ER. This suggests that, as in hepatocytes [33], TGs are assembled in the ER of beta cells. These vacuoles were not specific to beta cells since a similar localisation was noted in kidney $\operatorname{COS} 7$ cells. When heated to $70^{\circ} \mathrm{C}$ to
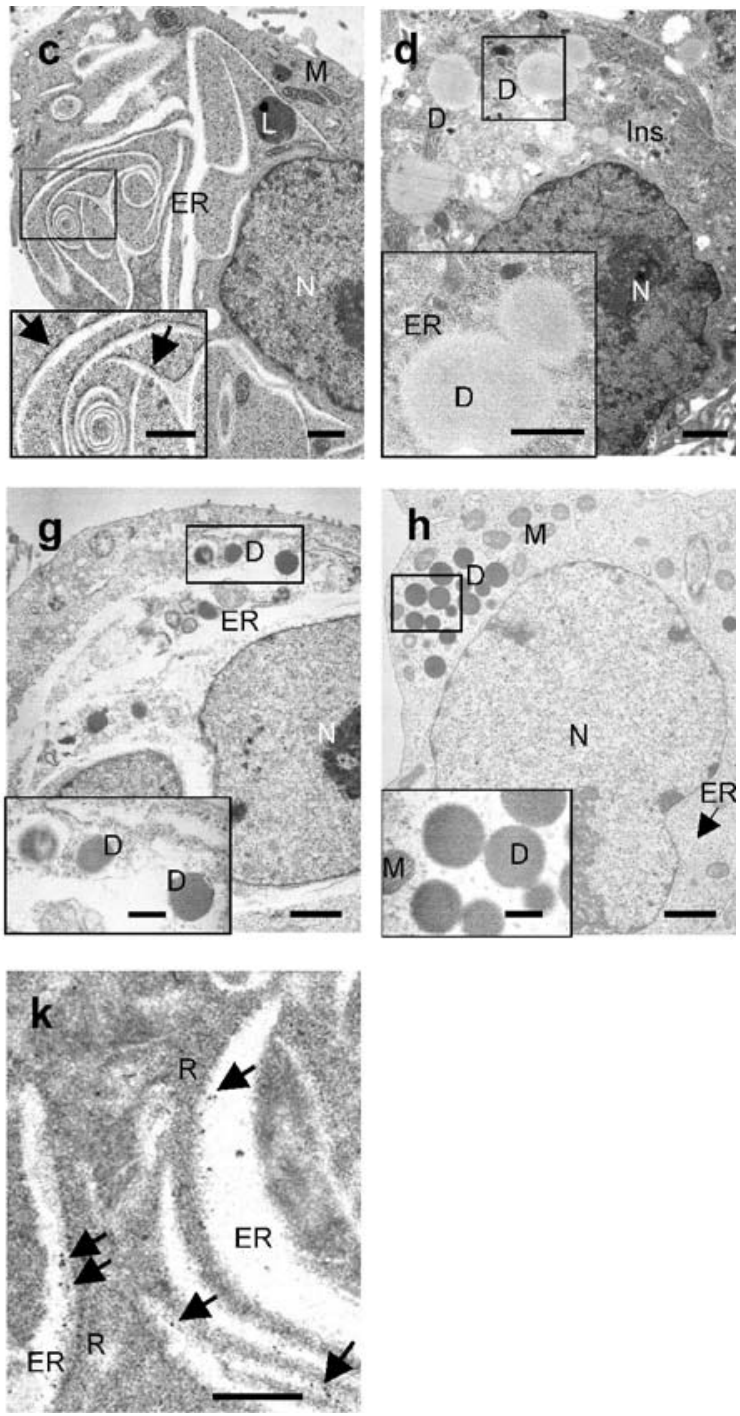

in the dilated ER (inset). (h) COS7 cells incubated with linoleic acid. Numerous electron-dense small droplets without a limiting membrane were visible in the cytoplasm (inset). (i) INS1 incubated with a mixture of 1:2 palmitic:oleic acids (final concentration $0.5 \mathrm{mmol} / \mathrm{l})$. Both vacuoles and electron-dense droplets were present (inset). (j) INS1 incubated with a mixture of 2:1 palmitic:oleic acids. The vacuoles were present as with palmitic acid alone but no droplets were visible. (k) INS1 incubated with palmitic acid and immunolabelled for the ER enzyme protein disulphide isomerase. Immunogold particles $(15 \mathrm{~nm})$ are situated on the borders of the vacuoles (arrows) close to the ribosomes, indicating that the vacuoles are distended ER. Ins, insulin granules; D, lipid droplets; M, mitochondrion; N, nucleus; ER, endoplasmic reticulum; L, lysosome, $R$, ribosomes. Scale bars; $\mathbf{a}, \mathbf{b}, \mathbf{c}, \mathbf{d}, \mathbf{i}, \mathbf{j}=1 \mu \mathrm{m}, \mathbf{e}, \mathbf{f}, \mathbf{g}, \mathbf{h}=2 \mu \mathrm{m}$, $\mathbf{k}$ and insets $=0.5 \mu \mathrm{m}$

allow increased fluidity of the TGs (Figs. 6h, 7h), lipid droplets were formed, as demonstrated by light and electron microscopy. These observations are consistent with non-physiological retention of tripalmitin in the endoplasmic reticulum, with severe disruption of the cellular architecture that would contribute to cell death. In contrast, in oleate-treated cells, which had much higher accumulation of lipid, largely in the form of triolein (melting temperature $5.5^{\circ} \mathrm{C}$ ) [38], lipid was present in droplets situated in the 
cytoplasm, yet cell viability was $100 \%$ at $0.5 \mathrm{mmol} / 1 \mathrm{NEFA}$ and $20 \mathrm{mmol} / \mathrm{l}$ glucose. Cell viability was therefore unrelated to the amount of TG stored. The concentration of albumin has been shown to be important in NEFA experiments [18, 39]; $0.5 \%$ was selected since this had no effect in itself on insulin secretion but effectively bound the NEFA up to $0.5 \mathrm{mmol} / 1$ concentrations [29]. At $1.0 \mathrm{mmol} / 1$ NEFA, $0.5 \%$ albumin there was an increase in cytotoxicity with all fatty acids, suggesting inadequate albumin binding.

Addition of unsaturated fatty acids protects cells from deleterious effects of palmitic acid in vitro [29]. This is supported by our data (Fig. 1b). Cytotoxicity was reduced from 40 to $0 \%$ by reducing the palmitate fraction in the incubation medium from 100 to $66 \%$. The incorporation of unsaturated fatty acids into otherwise palmitic-acid-rich TGs (Fig. 3b,c) would lower the molecular melting temperature and introduce more fluidity to the TG structure [40]. It is evident from the data that a proportion of tripalmitin of $20 \%$ or less does not induce beta cell cytotoxicity, whereas if tripalmitin forms greater than $60 \%$ of the TG, more than $20 \%$ cell death occurs (Figs. 1 and 3). The appearance of small droplets in the distended ER (Fig. 7h) of cells incubated in a mixture of oleic and palmitic acids supports this hypothesis. The TGs formed in cells exposed to 1:1 mixtures of palmitic and oleic acids indicated no selectivity of fatty acid acylation. Thus, we propose that the 'protection' in this type of in vitro study is simply and primarily due to the physicochemical properties of the stored TGs rather than any other major pathophysiological effect. Palmitic-acid-induced IL-6 production from myocytes in vitro was similarly prevented by addition of unsaturated fatty acids and was independent of betaoxidation [41]. Both INS1 and COS7 cell lines showed a reduction in cell viability. Taken together, these data suggest that similar in vitro effects of palmitic acid are found in many cell types.

The exact mechanism of the cytotoxic effect of NEFA is unclear. It has been suggested that formation of ceramides [42], free radicals [43] and cytokines [44] and the induction of apoptotic pathways [21] could be involved. NEFA induce ER stress response genes (nuclear factor $\mathrm{kB}$ [NFKB]) in beta cells [45] in a similar, but not identical, way to that of cytokines (IL- $1 \beta$, TNF- $\alpha$ ) [44]; these effects were shown to be more pronounced in cells exposed to palmitic than oleic acid [44, 45]. TGs that are rich in saturated fatty acids remain in the ER of cells and could trigger induction of ER stress response proteins, leading to apoptotic death [46]. Recently it has been shown that factors related to oxidative stress (reactive oxygen species and nitric oxide) and palmitate-derived ceramides are not causative factors for loss of GSIS following chronic exposure to NEFA [37]. These data, together with the observations that non-toxic concentrations of unsaturated NEFA result in loss of GSIS, suggest that the effects of lipids on insulin secretion and cell viability are unrelated.

Our results show that within $24 \mathrm{~h}$ the composition of the cellular phospholipid fraction is modified by the NEFA in the incubate. This is in agreement with previous studies on beta cells [47]. Changes in the composition of phospholipids, particularly incorporation of saturated NEFA, has implications for cell membrane rigidity and fluidity which could affect membrane signalling, insulin secretion by granule trafficking, fusion of secretory granules to the cell membrane during exocytosis, and protein processing in the endoplasmic reticulum $[47,48]$. In addition, the composition of phospholipids in lipid rafts has been shown to be affected by dietary lipids [49], which has implications for cellular functions such as the recycling of receptors and endocytosis.

Although subtle changes occur in specific plasma fatty acid ratios in obesity, a mixture of saturated and unsaturated NEFA still circulates [34]. Some reports of in vitro experiments using palmitic acid as a surrogate for in vivo conditions of elevated saturated lipids have clouded the view of the putative cytoxicity of fatty acids. Whereas isolated cells are able to take up and metabolise saturated lipids [50], in the absence of unsaturated NEFA they are unable to form a normal mixture of TG stores. This results in cell death via the morphological changes we have shown. The behaviour of INS1 cells and primary islets may differ in this respect. These marked changes in beta cell morphology with concomitant destruction of cell integrity are likely to mask the more subtle metabolic changes occurring due to physiological changes in fatty acid concentration and composition. The hypothesis that lipidinduced beta-cell death (lipoapoptosis) is a major aetiological factor in type 2 diabetes has evolved partly from such in vitro investigations. Our data would suggest that decreased GSIS derives from an imbalance in the sensitive interaction between glucose and lipid metabolism [51] coupled with important changes in phospholipids in beta cells. We believe that 'lipotoxicity' describes a metabolic dysregulation rather than a cellular insult and should therefore not be studied in cell models supplying a single species of saturated fatty acid.

Acknowledgements We are grateful to the Wellcome Trust for funding (J. H. Moffitt, B. A. Fielding, A. Clark); the Trust also provided funding for the electron microscope in the Department of Human Anatomy and Genetics, Oxford, and for the gas chromatograph (Oxford Centre for Diabetes, Endocrinology and Metabolism). Glucose-sensitive INS1 cells were kindly provided by Prof. G. Hitman (London). We thank Sarah Rodgers for her technical expertise with electron microscopical techniques, and Prof. John Morris (Department of Human Anatomy and Genetics), Dr. Fredrik Karpe and Prof. Keith Frayn (Oxford Centre for Diabetes, Endocrinology and Metabolism) for invaluable support and advice. We thank Prof David Vaux (Dunn School of Pathology, Oxford) for his advice and for the antibody to protein disulphide isomerase. The use of the NERC mass spectrometry facility (grant no. F14/6/13) is gratefully acknowledged.

\section{References}

1. Carpentier A, Giacca A, Lewis GF (2001) Effect of increased plasma non-esterified fatty acids (NEFA) on arginine-stimulated insulin secretion in obese humans. Diabetologia 44:19891997 
2. Dobbins RL, Szczepaniak LS, Myhill J et al (2002) The composition of dietary fat directly influences glucose-stimulated insulin secretion in rats. Diabetes 51:1825-1833

3. Segall L, Lameloise N, Assimacopoulos-Jeannet F et al (1999) Lipid rather than glucose metabolism is implicated in altered insulin secretion caused by oleate in INS-1 cells. Am J Physiol Endocrinol Metab 277:E521-E528

4. Randle PJ, Garland PB, Hales CN, Newsholme EA (1963) The glucose fatty-acid cycle. Its role in insulin sensitivity and the metabolic disturbances of diabetes mellitus. Lancet 1:785-789

5. Zhou YP, Grill VE (1994) Long-term exposure of rat pancreatic islets to fatty acids inhibits glucose-induced insulin secretion and biosynthesis through a glucose fatty acid cycle. J Clin Invest 93:870-876

6. Roche E, Farfari S, Witters LA et al (1998) Long-term exposure of beta-INS cells to high glucose concentrations increases anaplerosis, lipogenesis, and lipogenic gene expression. Diabetes 47:1086-1094

7. Prentki M, Corkey BE (1996) Are the beta-cell signaling molecules malonyl-CoA and cystolic long-chain acyl-CoA implicated in multiple tissue defects of obesity and NIDDM? Diabetes 45:273-283

8. Corkey BE, Deeney JT, Yaney GC, Tornheim K, Prentki M (2000) The role of long-chain fatty acyl-CoA esters in beta-cell signal transduction. J Nutr 130:299S-304S

9. Roduit R, Nolan C, Alarcon C et al (2004) A role for the malonyl-CoA/long-chain acyl-CoA pathway of lipid signaling in the regulation of insulin secretion in response to both fuel and nonfuel stimuli. Diabetes 53:1007-1019

10. Mulder H, Holst LS, Svensson H et al (1999) Hormonesensitive lipase, the rate-limiting enzyme in triglyceride hydrolysis, is expressed and active in beta-cells. Diabetes 48:228232

11. Fex M, Olofsson CS, Fransson U et al (2004) Hormonesensitive lipase deficiency in mouse islets abolishes neutral cholesterol ester hydrolase activity but leaves lipolysis, acylglycerides, fat oxidation, and insulin secretion intact. Endocrinology 145:3746-3753

12. Gremlich S, Bonny C, Waeber G, Thorens B (1997) Fatty acids decrease IDX-1 expression in rat pancreatic islets and reduce GLUT2, glucokinase, insulin, and somatostatin levels. J Biol Chem 272:30261-30269

13. Bollheimer LC, Skelly RH, Chester MW, McGarry JD, Rhodes CJ (1998) Chronic exposure to free fatty acid reduces pancreatic beta cell insulin content by increasing basal insulin secretion that is not compensated for by a corresponding increase in proinsulin biosynthesis translation. J Clin Invest 101: 1094-1101

14. Chan CB, Saleh MC, Koshkin V, Wheeler MB (2004) Uncoupling protein 2 and islet function. Diabetes 53(Suppl 1): S136-S142

15. Patane G, Anello M, Piro S et al (2002) Role of ATP production and uncoupling protein-2 in the insulin secretory defect induced by chronic exposure to high glucose or free fatty acids and effects of peroxisome proliferator-activated receptor-gamma inhibition. Diabetes 51:2749-2756

16. Unger RH, Orci L (2002) Lipoapoptosis: its mechanism and its diseases. Biochim Biophys Acta 1585:202-212

17. El-Assaad W, Buteau J, Peyot ML et al (2003) Saturated fatty acids synergize with elevated glucose to cause pancreatic betacell death. Endocrinology 144:4154-4163

18. Cnop M, Hannaert JC, Hoorens A, Eizirik DL, Pipeleers DG (2001) Inverse relationship between cytotoxicity of free fatty acids in pancreatic islet cells and cellular triglyceride accumulation. Diabetes 50:1771-1777

19. Briaud I, Harmon JS, Kelpe CL, Segu VB, Poitout V (2001) Lipotoxicity of the pancreatic beta-cell is associated with glucose-dependent esterification of fatty acids into neutral lipids. Diabetes 50:315-321

20. Maedler K, Spinas GA, Dyntar D et al (2001) Distinct effects of saturated and monounsaturated fatty acids on beta-cell turnover and function. Diabetes 50:69-76
21. Roche E, Buteau J, Aniento I et al (1999) Palmitate and oleate induce the immediate-early response genes c-fos and nur-77 in the pancreatic beta-cell line INS-1. Diabetes 48:2007-2014

22. Wang L, Folsom AR, Zheng ZJ, Pankow JS, Eckfeldt JH (2003) Plasma fatty acid composition and incidence of diabetes in middle-aged adults: the Atherosclerosis Risk in Communities (ARIC) Study. Am J Clin Nutr 78:91-98

23. Agren G, Narbro K, Naslund I, Sjostrom L, Peltonen M (2002) Long-term effects of weight loss on pharmaceutical costs in obese subjects. A report from the SOS intervention study. Int J Obes Relat Metab Disord 26:184-192

24. Ford ES, Giles WH, Dietz WH (2002) Prevalence of the metabolic syndrome among US adults: findings from the third National Health and Nutrition Examination Survey. JAMA 287:356-359

25. Prentki M, Joly E, El-Assaad W, Roduit R (2002) MalonylCoA signaling, lipid partitioning, and glucolipotoxicity: role in beta-cell adaptation and failure in the etiology of diabetes. Diabetes 51(Suppl 3)S405-S413

26. Poitout V, Robertson RP (2002) Minireview: secondary betacell failure in type 2 diabetes - a convergence of glucotoxicity and lipotoxicity. Endocrinology 143:339-342

27. Burdge GC, Wright P, Jones AE, Wootton SA (2000) A method for separation of phosphatidylcholine, triacylglycerol, nonesterified fatty acids and cholesterol esters from plasma by solid-phase extraction. Br J Nutr 84:781-787

28. Vaux D, Tooze J, Fuller S (1990) Identification by anti-idiotype antibodies of an intracellular membrane protein that recognizes a mammalian endoplasmic reticulum retention signal. Nature 345:495-502

29. Maedler K, Oberholzer J, Bucher P, Spinas GA, Donath MY (2003) Monounsaturated fatty acids prevent the deleterious effects of palmitate and high glucose on human pancreatic betacell turnover and function. Diabetes 52:726-733

30. Listenberger LL, Han X, Lewis SE et al (2003) Triglyceride accumulation protects against fatty acid-induced lipotoxicity. Proc Natl Acad Sci U S A 100:3077-3082

31. Briaud I, Rouault C, Reach G, Poitout V (1999) Long-term exposure of isolated rat islets of Langerhans to supraphysiologic glucose concentrations decreases insulin mRNA levels. Metabolism 48:319-323

32. Greenspan P, Mayer EP, Fowler SD (1985) Nile red: a selective fluorescent stain for intracellular lipid droplets. J Cell Biol 100:965-973

33. Hussain MM (2000) A proposed model for the assembly of chylomicrons. Atherosclerosis 148:1-15

34. Vessby B, Aro A, Skarfors E et al (1994) The risk to develop NIDDM is related to the fatty acid composition of the serum cholesterol esters. Diabetes 43:1353-1357

35. Paolisso G, Tagliamonte MR, Rizzo MR et al (1998) Lowering fatty acids potentiates acute insulin response in first degree relatives of people with type II diabetes. Diabetologia 41:11271132

36. Wrede CE, Dickson LM, Lingohr MK, Briaud I, Rhodes CJ (2002) Protein kinase B/Akt prevents fatty acid-induced apoptosis in pancreatic beta-cells (INS-1). J Biol Chem 277: 49676-49684

37. Moore PC, Ugas MA, Hagman DK, Parazzoli SD, Poitout V (2004) Evidence against the involvement of oxidative stress in fatty acid inhibition of insulin secretion. Diabetes 53:2610 2616

38. Small DM (1991) The effects of glyceride structure on absorption and metabolism. Annu Rev Nutr 11:413-434

39. Yaney GC, Korchak HM, Corkey BE (2000) Long-chain acyl $\mathrm{CoA}$ regulation of protein kinase $\mathrm{C}$ and fatty acid potentiation of glucose-stimulated insulin secretion in clonal beta-cells. Endocrinology 141:1989-1998

40. Timmen H, Patton S (1988) Milk fat globules: fatty acid composition, size and in vivo regulation of fat liquidity. Lipids $23: 685-689$ 
41. Weigert C, Brodbeck K, Staiger H et al (2004) Palmitate, but not unsaturated fatty acids, induces the expression of interleukin-6 in human myotubes through proteasome-dependent activation of nuclear factor-kappaB. J Biol Chem 279:23942-23952

42. Lupi R, Dotta F, Marselli L et al (2002) Prolonged exposure to free fatty acids has cytostatic and pro-apoptotic effects on human pancreatic islets: evidence that beta-cell death is caspase mediated, partially dependent on ceramide pathway, and Bcl-2 regulated. Diabetes 51:1437-1442

43. Robertson RP, Harmon J, Tran PO, Tanaka Y, Takahashi H (2003) Glucose toxicity in beta-cells: type 2 diabetes, good radicals gone bad, and the glutathione connection. Diabetes 52: 581-587

44. Welters HJ, Tadayyon M, Scarpello JH, Smith SA, Morgan NG (2004) Mono-unsaturated fatty acids protect against beta-cell apoptosis induced by saturated fatty acids, serum withdrawal or cytokine exposure. FEBS Lett 560:103-108

45. Kharroubi I, Ladriere L, Cardozo AK et al (2004) Free fatty acids and cytokines induce pancreatic beta-cell apoptosis by different mechanisms: role of NF-kappaB and endoplasmic reticulum stress. Endocrinology 145:5087-5096
46. Hitomi J, Katayama T, Eguchi Y et al (2004) Involvement of caspase- 4 in endoplasmic reticulum stress-induced apoptosis and $A \beta$-induced cell death. J Cell Biol 165:347-356

47. Ramanadham S, Hsu F, Zhang S et al (2000) Electrospray ionization mass spectrometric analyses of phospholipids from INS-1 insulinoma cells: comparison to pancreatic islets and effects of fatty acid supplementation on phospholipid composition and insulin secretion. Biochim Biophys Acta 1484:251266

48. Simons K, Toomre D (2000) Lipid rafts and signal transduction. Nat Rev Mol Cell Biol 1:31-39

49. Fan YY, McMurray DN, Ly LH, Chapkin RS (2003) Dietary $(n-3)$ polyunsaturated fatty acids remodel mouse T-cell lipid rafts. J Nutr 133:1913-1920

50. Parker SM, Moore PC, Johnson LM, Poitout V (2003) Palmitate potentiation of glucose-induced insulin release: a study using 2bromopalmitate. Metabolism 52:1367-1371

51. Yaney GC, Corkey BE (2003) Fatty acid metabolism and insulin secretion in pancreatic beta cells. Diabetologia 46 : $1297-1312$ 